\title{
INFORMAL LABOUR MARKETS AS A SOLUTION FOR UNEMPLOYMENT IN SOUTH AFRICA - A CASE STUDY OF CAR GUARDS IN BLOEMFONTEIN
}

\author{
P F BLAAUW \\ Department of Economics \\ Rand Afrikaans University \\ L J BOTHMA \\ Economic Advisor
}

\begin{abstract}
The car guard industry in South Africa evolved out of the plight of the unemployed. Very little research has been done on the industry in South Africa. The first objective of this article is to address the lack of research and the second is to determine whether the car guard industry can provide a solution to the problem of unemployment. Car guards involved in this study were found to be generally low skilled, earning low income and working under harsh conditions for long hours. The majority of them held formal sector employment before becoming unemployed. Car guarding is not a solution to the plight of the unemployed. Training and skill development supplemented by accelerated economic growth are vital to bridge the gap between the formal and informal sectors.
\end{abstract}

\section{OPSOMMING}

Die motorwag-industrie in Suid Afrika het onstaan uit die lot van die massa werkloses in die land. Weinig navorsing is al oor die industrie gedoen. Die doelwit van die artikel is eerstens om die gebrek aan navorsing aan te vul en tweedens om te bepaal of die motorwagindustrie 'n oplossing vir die probleem van werkloosheid kan bied. Motorwagte in die studie is oor die algemeen laag geskoold, swak besoldig en werksaam vir lang ure onder moeilike omstandighede. Die meeste het 'n werk in die formele sektor van die ekonomie gehad voordat hulle werkloos geword het. Om 'n motorwag te wees kan nooit 'n oplossing vir werkloosheid wees nie. Opleiding en die ontwikkeling van noodsaaklike vaardighede teen 'n agtergrond van versnelde ekonomiese groei, is uiters noodsaaklik om die gaping tussen die informele en formele sektor te oorbrug.

Literature on unemployment in South Africa is unanimous in its message. Unemployment is one of the major macroeconomic problems facing this country. Employment in the formal sector has shown a steady decline during the last decade in spite of an increase of 2,6 per cent in measured formal sector employment in the non-agricultural sector of the economy during the second quarter of 2002 (South African Reserve Bank, 2002, p. 13). This was the first time since early 1999 that measured formal sector employment actually increased in any calendar quarter (South African Reserve Bank, 2002, p. 2). This follows declines of 3,5 per cent in 1998; 2,0 per cent in 1999; 2,7 per cent in 2000 and 1,6 per cent in 2001 respectively (South African Reserve Bank, 2002 , p. 13). The increase in employment in the second quarter of 2002 however had little impact on the overall excess supply of labour in the economy (South African Reserve Bank, 2002, p. 2). The amount of new jobs being created in high-skilled sectors like trade and private services is marginal compared to the employment opportunities lost in the low and semi-skilled sectors of the economy (Loots, 1998, p. 332).

Unemployment is expected to increase because the number of new entrants into the labour market far outweighs the employment opportunities that can be created in the formal sector, given the current economic conditions in South Africa (Klasen \& Woolard, 1999, p. 4). Dri-Wefa, assuming an average economic growth rate of 2,5 per cent per annum, estimated formal employment to increase by 0,1 per cent or 11000 jobs per annum up to 2007. An increase in informal and selfemployment of 5,9 per cent per year up to 2007 was estimated at the same time (Barker, 2003, pp. 215-216). The informal sector is defined as follows: "Unorganised, unregulated and mostly legal but unregistered economic activities that are individually or family owned and use simple, labour intensive technology" (Barker, 2003, p. xix). This coincides with Statistics South Africa's definition of informal sector employment, namely: “...unregistered business, run from

Requests for copies should be addressed to: PF Blaauw, Department of Economics, RAU University, PO Box 524, Auckland Park, 2006 homes, street pavements or other informal arrangements" (Reinhardt, 2001, p. 2). Many workers who are not able to find employment in the formal sector of the economy can expect to find an income from work in the informal sector (Schlemmer \& Levitz, 1998, p. 7).

The car guard industry in South Africa evolved out of the plight of the unemployed, coupled with the increasing levels of crime, especially motor theft in South Africa. The industry therefore started of as an alternative source of income for people who were not able to secure employment in the formal sector of the economy. Except for the occasional article in the daily press, very little research has been done on the car guard industry in South Africa. Kitching conducted the only known study in this field in 1999 in Bloemfontein.

Since February 2002 Statistics South Africa uses a twice-yearly household survey to calculate employment and unemployment levels in the country. This survey, known as the Labour Force Survey (LFS), covers both the formal and the informal sectors of the economy. According to this the official rate of unemployment was 30,5 per cent in September 2002 (Statistics South Africa, 2003, p 8). Using the expanded definition of unemployment i.e. dropping the requirement that a person had to be engaged in job seeking activities in the four weeks prior to the interview, the rate of unemployment was calculated at 42,8 per cent (Statistics South Africa, 2003, p. 19).

Although these figures are highly valued, it merely provides a snapshot picture of the labour market at a particular point in time. Focusing on this static picture only masks the highly dynamic nature of labour markets (Ehrenberg \& Smith, 1988, p. 587). Unemployment figures does not distinguish between people who are experiencing short, less serious, spells of unemployment and those who are going through long periods where they are unable to find employment. Over time alternative models of the labour market were developed, taking this characteristic into account. The stock-flow model is an example of this evolvement (McConnell \& Brue, 1999, pp. 569-570). Every 
person in the non-institutional population is in one of three categories: employed, unemployed, or not in the labour force. These stocks are continuously depleted and replenished by numerous flows into and out of each category (Kaufman \& Hotchkiss, 2000, p. 670).

Some people are stuck in the unemployed category for a long period of time. Eventually they do not have any other choice than to venture into the informal sector of the economy to raise income. The car guard industry developed as a result of this movement to the informal sector of the economy. Studying this industry could provide us with valuable insight into the problem of unemployment, instead of merely calculating a rate of unemployment.

Against this background, the following research problem can be postulated. The informal sector of the economy is providing a source of income for more and more people who cannot find employment in the formal sector of the economy. Can an informal labour market like car guarding be regarded as a solution to the plight of the unemployed?

\section{Aim of the research}

The aim of this article is to answer the following research questions stemming from the research problem:

1. Is it possible to obtain more scientific information about the car guard industry?

2. Can the car guard industry provide a solution for the problem of unemployment?

The research questions are answered by applying the stock-flow model of the labour market to the car guard industry. In order to achieve this, a follow-up on Kitching's study on the guard industry in Bloemfontein, was undertaken.

The article is deployed as follows. The first section provides a brief background of the car guard industry. The research method is explained, followed by the results of the survey and an analysis of the insight it offers on the issue of unemployment.

\section{Background and evolvement of the car guard industry}

According to Kitching (1999, p. 7), the car guard industry started as a very informal activity. Unemployed people started offering their services on an ad hoc basis in exchange for a donation, to motorists at municipal parking spaces in the central business districts (CBD'S) of cities.

The last couple of years saw the evolvement of a new group of car guards. This group guards cars at sporting events, schools, hospitals, churches, restaurants and especially shopping centres. They are organised and are easily recognised by shirts or jackets, displaying the name of one or other car guard organisation. The first of these, Car Watch, was established in Durban in December 1995. The concept spread very quickly and similar organisations shot up all over South Africa. These organisations maintain that they are not employing the car guards. The guards are merely hiring the equipment and jackets from the organisation. Car guards are therefore entirely responsible for their own daily income (Kitching, 1999, p. 1-3).

Recent developments have seen a greater degree of formalisation in the car guard industry. According to section six of the Security Officers Act (Act no. 92 of 1987), people rendering a security service, is required to register as security officials with the Security Officers Board of South Africa. This is important as it goes a long way to formalise the activities of car guards. It does indeed raise the question whether car guards, attached to formal car guard organisations, can still be regarded as part of the informal sector of the economy? For the purpose of this article they are assumed to be part of the informal sector. This coincides with the two definitions of the informal sector provided in the second paragraph of the article. The guards in the CBD are without doubt still very much informal. These are people that are not attached at all to any formal organisation and are well and truly self-employed.

\section{METHOD}

The following definitions were accepted for the purpose of this research. A car guard was regarded as someone who, in exchange for a donation, offers to guard vehicles in a public or private parking area. The amount of the donation is at the discretion of the motorist.

Stemming form this definition, two populations were identified. One group was the informal car guards in the municipal parking areas of the central business district (CBD) in Bloemfontein. The second group was the so-called formal car guards, active mainly at the private parking areas of shopping centres in the city. An effort was made to incorporate all car guards in the survey. This was not a problem as far as the informal ones were concerned. With regard to the formal car guards however, one car guard organisation did not want their guards to be part of the survey.

Since it was expected that some car guards might be illiterate, the survey took the form of scheduled and structured interviews. This method ensures that there are no misunderstandings and misinterpretations of questions (Bless \& Higson-Smith, 1995, p. 111). A questionnaire consisting of two parts was used for this purpose. The first section contained questions pertaining to the demographic features and working conditions of car guards. The second part included questions necessary to apply the stock-flow model of unemployment to the car guard industry. The interviews were conducted in March 2001. Questionnaires were completed for 88 formal and 61 informal car guards respectively.

\section{RESULTS}

Table 1 provides a summary of the results of the survey in Bloemfontein. It describes the demographic features and working conditions of formal and informal car guards and provides the scientifically obtained information required by the first research question.

The formal car guards are mainly white, all of which are Afrikaans speaking. The informal ones are mostly black and coloured people, speaking Sotho and Afrikaans respectively. Amongst the 88 formal car guards involved in the survey, were $60(68,2$ per cent) males and 28 ( 31,8 per cent) females. There were no women among the informal car guards.

The average age of the informal car guards is 30,5 years, as opposed to 38,7 years of their formal counterparts. However, formal car guards have on average fewer dependants $(1,7)$ than the informal ones $(2,3)$.

All respondents in the formal group indicated that they did attend school, while five $(6,7$ per cent) informal car guards said that they never received any formal schooling. Ten formal car guards passed grade 12 (matric), as opposed to only two informal ones. Four formal car guards achieved a qualification at a tertiary institution, but none of the informal ones did. Twenty $(22,7$ per cent) formal car guards received formal training in the form of an apprenticeship or acquired other labour market skills, while only four $(6,7$ per cent) informal car guards testified to that.

Income earned by car guards was defined as net or take home income. This is especially relevant for formal car guards. They must pay a daily amount of between twenty and twenty-five rand to their car guard organisations, from which they hire jackets or shirts. Average income per day was calculated by dividing the summation of the average daily net income of each car guard, by the number of respondents $(\mathrm{N})$. In this way it was determined that average income 
per day is R52,40 and R32,00 for formal and informal car guards respectively. Average income per hour was calculated as follows: each car guard's average daily income was divided by the average number of hours that he/she works per day. These values were added together and divided by the number of respondents $(\mathrm{N})$. The average income per hour for formal car guards is R5,70 while informal car guards earn on average R3,70 per hour.

TABle 1

A PROFILE OF CAR GUARDS IN BLOEMFONTEIN

\begin{tabular}{|c|c|c|}
\hline & FORMAL & INFORMAL \\
\hline Number (N) & 88 & 61 \\
\hline \multirow[t]{3}{*}{ Racial group } & 72 Whites (all Afrikaans) & 34 Blacks \\
\hline & 14 Blacks & 27 Coloured \\
\hline & 2 Coloured & \\
\hline \multirow[t]{2}{*}{ Gender } & 60 Males & 61 Males \\
\hline & 28 Females & \\
\hline Age & Average: 38,7 years & Average: 30,5 years \\
\hline Dependents & Average: 1,7 & Average: 2,3 \\
\hline \multirow[t]{3}{*}{ School Education } & All 88 attended school & 5 never attended school \\
\hline & 10 passed grade 12 & 2 passed grade 12 \\
\hline & 46 passed grade 10 & 23 only passed grade $1-7$ \\
\hline Tertiary Education & $\begin{array}{l}4 \text { had education at a } \\
\text { university, college, etc. }\end{array}$ & None \\
\hline Other formal after & $\begin{array}{l}12 \text { had apprenticeship- } \\
\text { training }\end{array}$ & 4 acquired some skills \\
\hline school training & 8 acquired some skills & \\
\hline $\begin{array}{l}\text { Days per week } \\
\text { working as car } \\
\text { guard }\end{array}$ & Average: 6,5 & Average: 5,5 \\
\hline $\begin{array}{l}\text { Working hours } \\
\text { per day }\end{array}$ & Average: 9,2 & Average: 8,6 \\
\hline Income per day & Average: R 52,40 & Average: R 32,00 \\
\hline Income per hour & Average: R 5,70 & Average: R 3,70 \\
\hline
\end{tabular}

With regard to working conditions, 79 (89,8 per cent) formal car guards indicated that they are on duty for at least six days per week. In fact, 54 (61,4 per cent) of these people work seven days per week. Fifty-five informal car guards (93,2 per cent) work at least five days per week. On average formal and informal car guards work 6,5 and 5,5 days per week respectively. The difference is most likely explained by the fact that informal car guards work at municipal parking areas, where there are virtually no motorists on Saturday afternoons and Sundays. As a result, there is no incentive for them to be on duty.

More than half of formal car guards (53,4 per cent) work between nine and ten hours per day. The average hours worked per day are 9,2 . Informal car guards work 8,6 hours per day on average. The difference is probably due to the fact that most businesses in the CBD - where the informal car guards are working - close at 17:00, reducing the number of motorists in the area.

In order to answer the second research question the flow of car guards through the respective categories of the stock-flow model of the labour market was determined. Figure 1 provides a graphical representation of the flows encountered by formal car guards.

Seventy-three (83 per cent) formal car guards indicated that they held positions in the formal sector of the economy, prior to becoming unemployed. In response to the question in which sector they were employed, 46 of the 73 (63 per cent) said they were engaged in the service sector of the formal economy.

Next formal car guards were asked how long their previous employer employed them in the formal sector. Forty-eight of the 73 (68 per cent) were employed for a period of up to five years. The rest (32 per cent) worked for longer than five years for their previous employer.

Respondents were also asked to state the reasons for leaving their previous employer. One of the seventy three retired and left the labour force. Of the remaining 72, 39 were laid off, 31 quitted and two were discharged.

The 72 respondents, who left the formal sector, were joined in the unemployed category by nine others, who entered the labour force for the first time, but were not able to secure a job immediately. These 81 people were asked how long they were unemployed. Forty-four (54 per cent) were jobless for less than a year. Of the rest - who were unemployed for more than a year seven searched more than five years for a job.

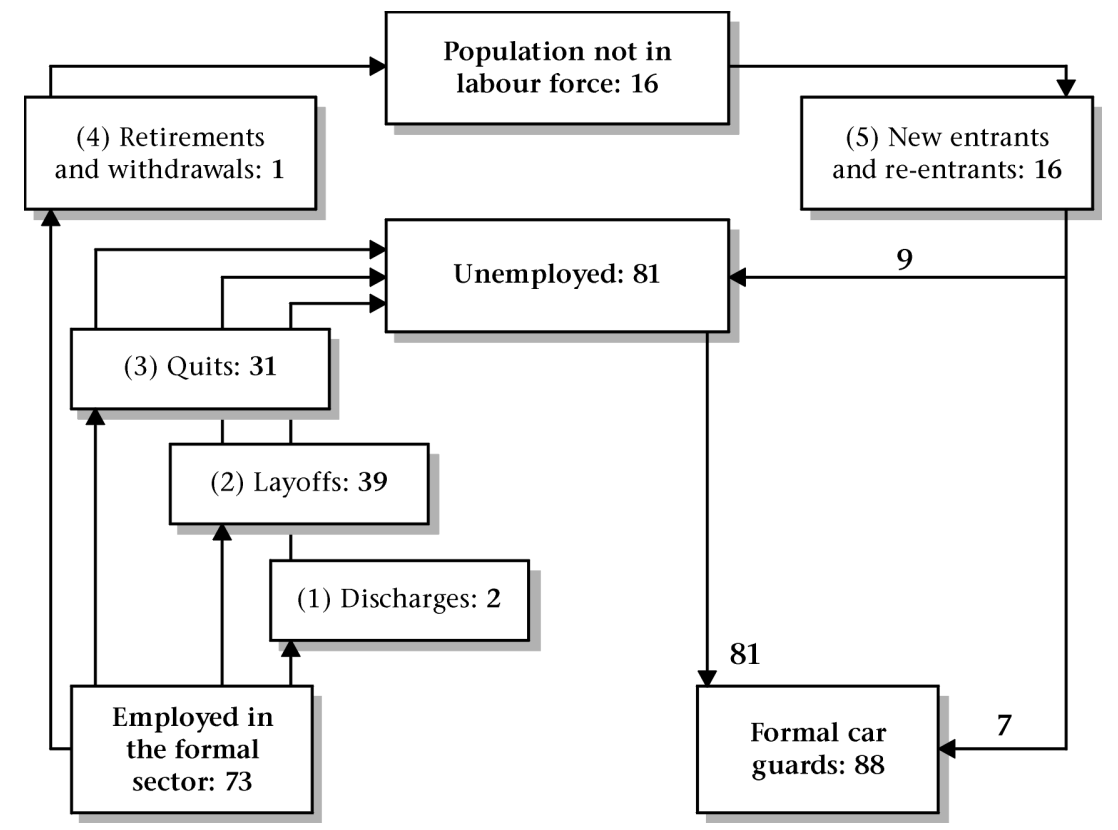

Figure 1: The stock-flow model - formal car guards 


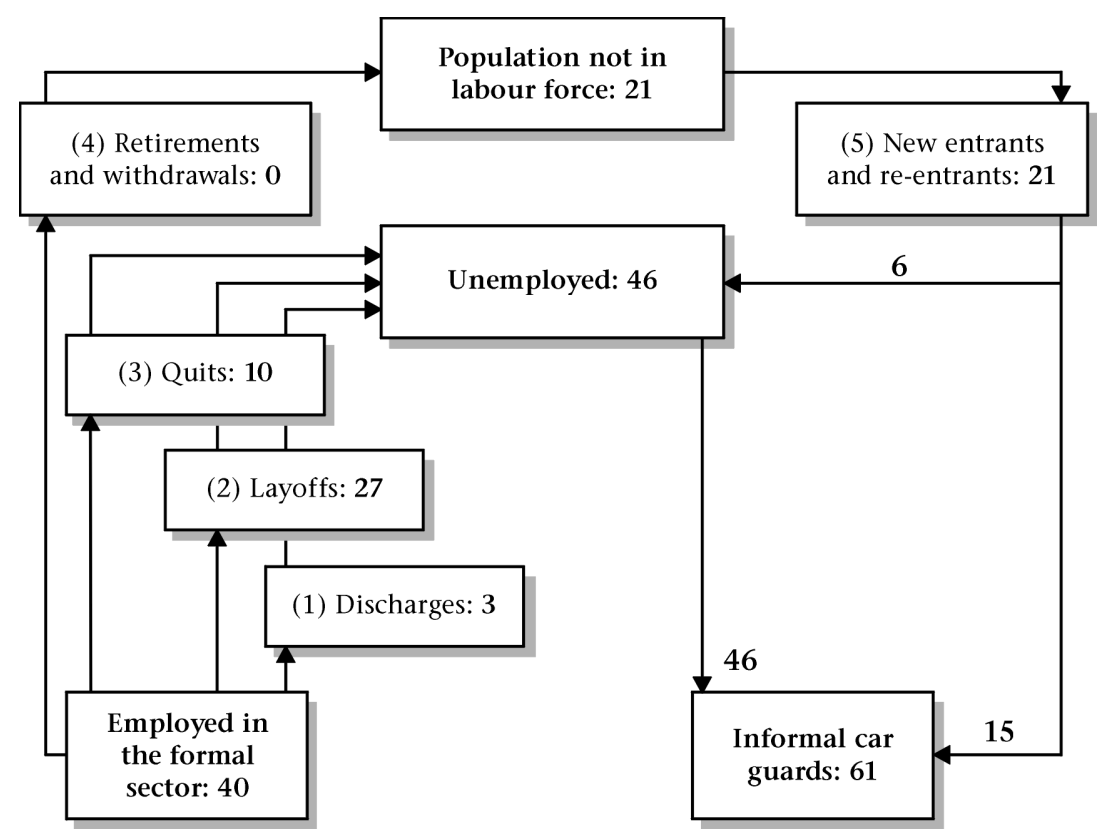

Figure 2: The stock-flow model - informal car guards

Eventually all 81 unemployed people ended up being car guards. Seven people, who entered the labour force for the first time, joined them. They were not unemployed for some time, but started working as car guards immediately.

The vast majority of formal car guards are involved with this activity for between 1 and 3 years. Yet most of them would like to find alternative employment. Sixty-nine (78 per cent) indicated that they would like to find other employment.

Figure 2 tracks the flows encountered by the informal car guards.

Although numbers and percentages differ, the same trends emerge when the stock-flow model is applied to informal car guards. Figure 2 shows that the majority (40) of the 61 informal car guards was at some stage employed in the formal sector of the economy. Most of them lost their jobs due to layoffs and quits, although there were some discharges as well.

No less than 15 informal car guards indicated that they never had any job in the formal sector of the economy. Unlike the $46 \mathrm{car}$ guards who were unemployed for some time, this 15 flowed straight from not being part of the labour force, to the informal sector of the economy.

In terms of the time being unemployed, informal car guards were less fortunate than their formal counterparts. Thirty- five (88 per cent) of the 40 , who were employed in the formal sector, was unemployed for up to 3 years.

Almost a third of all informal car guards have been engaged in this activity for more than five years. Many of them have never done anything else. Like their formal counterparts, the overwhelming majority (98,3 per cent) indicated that they would accept other employment if available.

\section{DISCUSSION}

It is evident from table 1 that the vast majority of the respondents are low and semi skilled people. The availability and level of skills of the labour force are playing an increasingly role in attracting foreign direct investment which creates future employment opportunities (Chetty, 2002, p. 10). The prospects for a speedy return to the formal sector are therefore not positive at all.
The average income per hour, calculated from the results of the survey, for formal car guards is R5,70 while informal car guards earn on average R3,70 per hour. To put the income of car guards into perspective, it was compared with the remuneration of waiters and domestic workers - two other low-paid occupations - in Bloemfontein. Table 2 provides a summary of the hourly compensation of these three occupations.

TABLE 2

HOURLY INCOME OF CAR GUARDS, WAITERS AND DOMESTIC WORKERS IN BLOEMFONTEIN

\begin{tabular}{lll}
\hline Car Guards (2001) & Domestic Workers (2001) & Waiters (2000) \\
\hline Formal: R5,70 & $\mathrm{R} 6,19$ & $\mathrm{R} 14,52$ \\
Informal: R3,70 & & \\
\hline
\end{tabular}

Source: ${ }^{1}$ Bothma \& Campher, 2002, p. 7.

2 Bothma \& Thomas, 2001, p. 269.

Table 2 shows that car guards earn the lowest hourly income of the three occupations. On average, an informal car guard's hourly income is 60 per cent of that of a domestic worker and a mere 25 per cent of that of a waiter. Although being a car guard provides a marginal means of survival, it cannot support an individual or a whole family. It does not provide skills or increase productivity levels and therefore contributes very little towards uplifting the poor. In comparison, formal sector jobs are relatively secured and well paid, providing incumbents with a certain level of skills (Reinhardt, 2001, p. 2).

The following conclusions were drawn from this case study. This study confirms that one cannot focus solely on unemployment statistics, as it disguises the complexity of the unemployment problem. Even though car guards are not officially regarded as unemployed, their flow through the labour market provides insight into the unemployment problem.

The study revealed that the majority of car guards previously held formal sector jobs. This corresponds with the continuous decline in formal sector employment throughout the South African economy. As the study showed, there are also those who enter the labour market for the first time, but cannot secure jobs. This adds to the ever-increasing number of unemployed people. 
Layoffs and quits were cited by respondents as the main reasons for unemployment. Layoffs mainly relate to cyclical and structural changes in the economy, while not all quits were voluntarily. Many female car guards indicated that they had to quit because of their husbands being transferred to other locations. This emphasizes that unemployment is not merely an issue involving individuals. It should be analysed within the context of families.

Although discharges were found to be a minor reason for job losses amongst respondents, it accentuates that lack of discipline, work ethics, and misconduct, also contribute towards unemployment.

Car guards involved in this study were found to be generally low skilled, earning low income and working under harsh conditions for long hours. On average, using the official definition of unemployment, Statistics South Africa (2003, p. 88) indicates that 26,3 per cent of the unemployed passed grade 12 . Only 8,05 per cent of the car guards in this survey can testify to that. At least half of all those who once held formal employment, indicated that they were unemployed for more than a year, before becoming car guards. The unsuccessful search for formal sector employment by the car guards in this case study is a direct consequence of the low level of education and skills among them.

Long spells of unemployment and low skill levels, make it extremely difficult for car guards to get back into the formal sector. The longer they are unemployed, the more redundant their skills - which are in any case low in demand - become. The availability and level of skills are playing an increasingly role in attracting the foreign direct investment South Africa needs to ensure higher levels of economic growth.

Economic growth on its own does not significantly contribute towards the creation of new job opportunities. The amount of new jobs being created in high-skilled sectors like trade and private services is marginal compared to the employment opportunities lost in the low and semi-skilled sectors of the economy. The development of existing and the acquiring of new skills that is in demand in the labour market are vital for these people. The solution to car guards' plight lies in training and or the acquisition of new skills coupled with accelerated economic growth.

To what extent then does car guarding provide a solution to the plight of the unemployed? Are car guarding not merely disguised unemployment and an example of the discouraged worker phenomenon? The study revealed that this activity at least provides some means of survival but nothing more than that. The overwhelming majority of the respondents said that they would accept other employment if available. Informal activities like these are no alternative to formal sector employment. The low level of income earned by car guards bore testimony to this. The aim should always be to bridge the gap between formal and informal employment. It must be remembered that the very existence of this activity, depends on the public's fear of crime. Without this fear less car guards will be needed and where will they go then?

\section{REFERENCES}

Barker, F. (2003). The South African Labour Market, $4^{\text {th }}$ edition. Pretoria; Van Schaik.

Bless, C. \& Higson-Smith, C. (1995). Fundamentals of Social Research Methods - an African Perspective, $2^{\text {nd }}$ edition. Cape Town: Juta.

Bothma, L.J. \& Campher, C.S. (2002). Minimum wages for domestic workers: A comparative analysis. Unpublished research paper, University of the Free State.

Bothma, L.J. \& Thomas, K. (2001). The enforcement of the BECA and waiters. South African Journal of Economic and Management Sciences, 4 (2), 263-73.

Chetty, S. (2002). Creating a sustainable climate for fixed capital formation in the South African Development Community (SADC). Research paper No 0205, Department of Economics, RAU.

Ehrenberg, R.G. \& Smith, R.S. (1988). Modern Labor Economics: Theory and Public Policy, $3^{\text {rd }}$ edition. Glenview, Illinois: Scott, Foresman and Company.

Kaufman, B.E. \& Hotchkiss, J.L. (2000). The Economics of Labour Markets, $5^{\text {th }}$ edition. Philadelphia: The Dryden Press.

Kitching, K. (1999). Die ekonomie van die motorwagbedryf: Bloemfontein as gevallestudie. Unpublished honours dissertation, University of the Free State, Bloemfontein.

Klasen, S. \& Woolard, I. (1999). Levels, trends and consistency of employment and unemployment figures in South Africa. Development Southern Africa, 16 (1), 3-35.

Loots, A.E. (1998). Job creation and economic growth. The South African Journal of Economics, 66 (3), 319-336.

McConnell, C.R. \& Brue, S.L. (1999). Contemporary Labor Economics, $5^{\text {th }}$ edition. New York: McGraw-Hill.

Reinhardt, A.M. (2001). OHS'98 - Is news really positive on the unemployment front? http://www.econometrix.co.za/00hot/ prew0700.htm

Schlemmer, L. \& Levitz, C. (1998). Unemployment in South Africa - the facts, the prospects and an exploration of solutions. Johannesburg: South African Institute of Race Relations.

Security Officers Act. (1987). Pretoria: Government Printer.

South African Reserve Bank. (2002). Quarterly Bulletin, December 2002. Pretoria.

Statistics South Africa. (2003). Labour Force Survey, September 2002. Pretoria 